\section{Trace Element Identification of the Source of Obsidian in an Archaeological Site in New Guinea}

OвsIDIAN artefacts were found in an archaeological site, in a level dated to $470 \mathrm{BC} \pm 110 \mathrm{yr}$ (ref. 1), on the island of Watom, 3 miles off the north coast of New Britain. To determino where this artefact obsidian originated, trace clement determinations were made on the artefacts and on five samples of volcanic glass from known occurrences.

The glasses are grey to black banded obsidian with conchoidal fracture except one from Rabaul, which is a black porphyritic glass with a blocky fracture. They were analysed for Ca, Mg, Fe, Mn, V, Ti, Nb, Zr, Sr, Ba, $\mathrm{La}$ and $\mathrm{Cu}$, using a Jarrell-ash Ebert grating spectrograph, calibrated using the international standard rock samples 2 .

There are three known obsidian occurrences in New Guinea separated by distances of 300 miles (personal communication from G. A. Taylor). The most northerly one is an old caldera rim now protruding above sea level on the islands of Lou and Baluan in the Admiralty group. South of this are the obsidian flows at Talasea on the Willaumcz Peninsula of New Britain. The third source is the Lamonai crater on Fergusson Island in the D'Entrecasteaux group off S.E. Papua.

The porphyritic glass occurs as cobble sized lumps in the lower tephra of the last major eruption of the Blanche Bay volcanic complex at Rabaul. All these volcanic centres are Pleistocene to Recent in age.

\begin{tabular}{|c|c|c|c|c|c|c|c|}
\hline & & Rabaul & Baluan & Lou Is. & Talasea & Fergusson & Watom \\
\hline $\mathrm{Ca}$ & Per cent & $2 \cdot 51$ & $1 \cdot 03$ & 0.88 & 0.94 & 0.53 & 0.82 \\
\hline $\mathrm{Mg}$ & & $0 \cdot 80$ & $0 \cdot 19$ & 0.17 & 0.12 & 0.12 & $0 \cdot 14$ \\
\hline $\mathrm{Fe}$ & & $3 \cdot 51$ & $2 \cdot 03$ & 1.61 & 0.91 & 0.94 & 0.91 \\
\hline Mn & P.p.m. & 1,030 & 630 & 550 & 490 & 340 & 470 \\
\hline V & & 65 & n.d. & n.d. & n.d. & n.d. & n.d. \\
\hline $\mathrm{Ti}$ & & 5,100 & 2,100 & 1,950 & 1,550 & 1,600 & 1,500 \\
\hline$\overline{\mathrm{N} b}$ & & n.d. & 50 & 54 & n.d. & n.d. & n.d. \\
\hline $\mathrm{Zr}_{\mathrm{r}}$ & & 170 & 400 & 310 & 140 & 270 & 140 \\
\hline $\mathrm{Sr}$ & & 320 & 120 & 90 & 250 & 130 & 200 \\
\hline $\mathrm{Ba}$ & & 570 & 1,000 & 920 & 740 & 1,000 & 650 \\
\hline $\mathrm{I} a$ & & n.d. & 50 & 35 & n.d. & 38 & n.d. \\
\hline $\mathrm{Cu}$ & & 20 & 7 & 6 & 5 & 3 & 7 \\
\hline
\end{tabular}

Table 1 shows the results of the spectrographic determinations. Fig. 1 shows the artefact values plotted along the vertical axis and those of the geological samples along the horizontal axis. Where these values are equal they fall on the $45^{\circ}$ line. Increasing distance away from

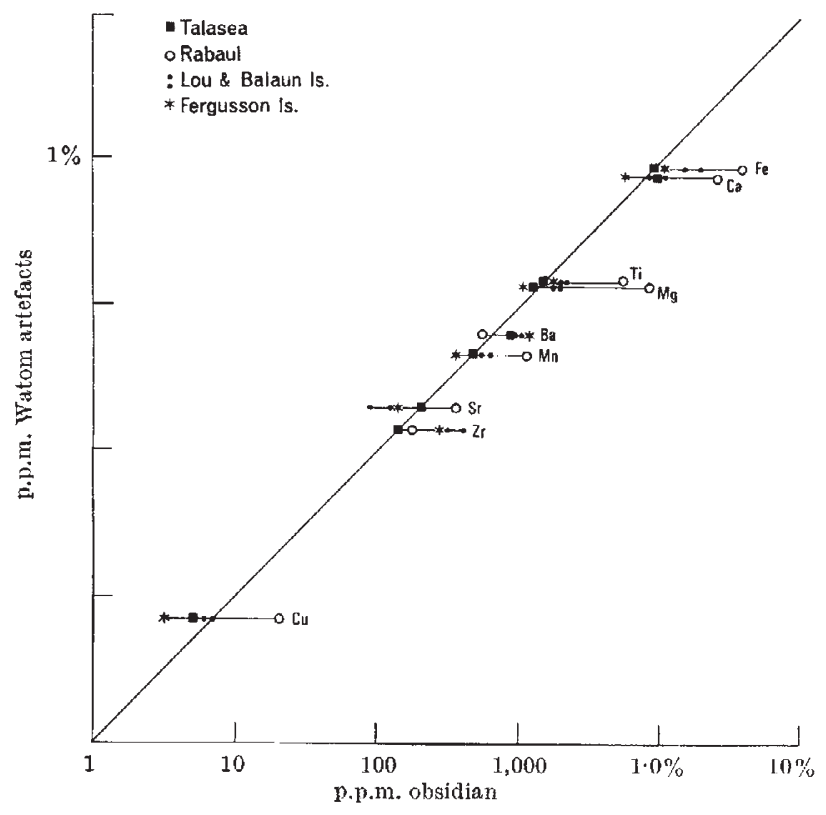

Fig. 1.

this line is a measure of increasing dissimilarity in composition. The diagram shows that the Rabaul glass differs most from the Watom artefacts.

The archaeological sample from Watom Island has a major and minor element composition virtually identical to that of the Talasea obsidian flow (filled squares in Fig. 1) and is very different from the Rabaul glass. The data indicate that the Talasea obsidian flow was the source of the obsidian in the Watom Island site.

The analyses were carried out in the spectrochernical laboratory of the Department of Geophysics and Geochemistry of the Australian National University, using the methods of Dr S. R. Taylor', whose help, and that of Mrs M. J. Kaye, is gratefully acknowledged. G. A. Taylor, of the Australian Burcau of Mineral Resources, supplied the samples of obsidian.

Department of Anthropology (Prehistory),

C. A. KEY

Australian National University,

Canberra.

Received May 13; revised June 24, 1968.

1 Polach, H., Radiocarbon, 10 (2) (in the press). ${ }^{2}$ Ahrens, L. H., and Taylor, S. R., Spectrochemical Analysis (Addison Wesley
Press, 1961).

\title{
Silica Balance of the Ocean
}

HARRISS ${ }^{1}$ recently published a silica budget for the ocean from which he concludes that the losses outweigh the gains by something like $8 \times 10^{15} \mathrm{~g} \mathrm{yr}^{-1}$ (Table 1). At this rate only about three centuries would be required to reduce the average silica content of seawater to 0.2 p.p.m., the minimum concentration supposed adequate to support diatoms.

Tablc 1. SILICA BLDGET FOR THE OCEAN (AFTER HARRISS) Silicon dioxide

Charge

Dissolved silica in continental drainage Dissolved silica from submarine weathering

Discharge

Silica removed as diatomic ooze in Antaretica Silica removed by organisms from rest of ocean

$$
\begin{aligned}
& \left(\mathrm{g} \mathrm{yr}^{-1}\right) \\
& 4 \cdot 3 \times 10^{14} \\
& 0.03 \times 10^{14} \\
& \hdashline 4 \cdot 3 \times 10^{14} \\
& 8 \quad \times 10^{14} \\
& 77 \quad \times 10^{14} \\
& \hline 85 \quad \times 10^{14}
\end{aligned}
$$

Silica is more concentrated in river waters (world average 13 p.p.m.) than in the sea (1-2 p.p.m.). As Harriss surmises, the pelagic organisms are probably spending all of the income. That they can fairly be accused of spending the capital as well is less certain, and before we can tell whether the concentration of silica in the ocean is changing, more precise estimates of charge and discharge will be required. $\Lambda$ contribution which cannot at present be evaluated is that of submarine volcanism; recent study of the ocean floors ${ }^{2}$ supports the idea that these spread away from the mid-ocean ridges at a rate implying the production of about $8 \mathrm{~km}^{3}$ of basalt per year, and there is no knowing how fast silica is added to the ocean by this process. On the debit side we have $7 \cdot 7 \times 10^{15} \mathrm{~g} \mathrm{yr}^{-1}$ used by organisms, but it is difficult, as Harriss points out, to estimate how much of this is really withdrawn in biogenic sediments and how much merely borrowed for the lifetime of the organisms. The red clay of the abyssal plains is practically devoid of biogenic silica, and it has long been known ${ }^{3}$ that the deeper waters of the Pacific are richer in dissolved silica than those nearer the surface; this suggests that most of the skeletons are dissolved again before sinking to the bottom. According to Holmes ${ }^{4}, 268 \times 10^{8} \mathrm{~km}^{2}$ of the ocean floor are covered by pelagic sediments, of which 7.5 per cent nro made up of biogenic silica. Taking the average thickness as $300 \mathrm{~m}$, we arrive at $6 \times 10^{6} \mathrm{~km}^{3}$ of siliceous sediments. Doubling this to be on the safe side and assuming a density of $2 \cdot 5$, we end with $3 \times 10^{22} \mathrm{~g}$. 